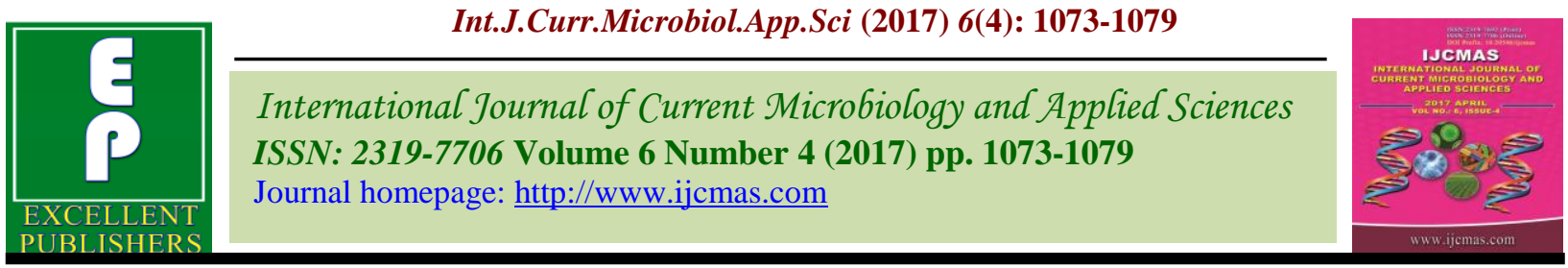

Original Research Article

https://doi.org/10.20546/ijcmas.2017.604.133

\title{
Quantitative Analysis of Phytochemicals in the Bark Extracts of Medicinally Important Plant Cassia fistula, Linn.
}

\author{
Suman Kumar Ratnampally* and Venkateshwar Chinna
}

Department of Botany, Osmania University, Hyderabad, Telangana, India
*Corresponding author

\section{A B S T R A C T}

\section{Keywords}

Cassia fistula,

Medicinal plant,

Quantitative

analysis,

Phytochemicals,

Gondu tribes.

Article Info

Accepted:

06 March 2017

Available Online:

10 April 2017
The present study was conducted to determine the yield of extract quantitatively for the crude bark extracts of Cassia fistula, family Fabaceae is a high value medicinal plant collected from Osmania University, Hyderabad, Telangana State. The basis for the present study is that the bark of this plant is used by Gondu tribes of Adilabad District, Telangana State, India to treat hyperthyroidism in human beings. The author has significantly documented the ethnobotanical relation of present plant under study. Since the advent of modern drug treatments, traditional medicine has greatly receded in occidental societies. Only a limited number of medicinal plants have received detailed scientific scrutiny thereby prompting the World Health Organization to recommend that this area be comprehensively investigated. The bark extracts were prepared by using Ethanol, Methanol, Acetone, Chloroform, Petroleum ether and also in water. The yields of extract were calculated as weight/weight in all the six solvents and are studied for eight phytochemical compounds. The present study revealed the presence of Alkaloids, Flavonoids, Total Phenols, Carbohydrates, Total Tannins, Saponins, Terpenoids, Total Glycosides in varying content and clearly shown that the more number of phytochemical compounds are maximum soluble in ethanol solvent.

\section{Introduction}

Phytochemicals are the chemicals produces by various parts of the plants. These bioactive constituents of plants are steroids, terpenoids, carotenoids, flavanoids, alkaloids, tannins and glycosides. These compounds have various activities such as antimicrobial and antibacterial some have been reported to exhibit hemolytic and foaming activity reported (Feroz et al., 1993). Qualitative phytochemical screening will help to understand a variety of chemical compounds produced by plants and quantification of those metabolites will help to extract, purify and identify the bioactive compounds for useful aspects to human beings. Plants have limitless ability to synthesize aromatic substances, mostly phenols or their oxygen-substituted derivatives (Geisssman, 1963). Most of the natural products are secondary metabolites and about 12,000 of such products have been isolated so far. These products serve as plant defence mechanisms against predation by microorganisms, insects and herbivores (Fransworth and Morris, 1976). Several bioactive constituents have been isolated and studied for pharmacological activities. During the last two decades, the pharmaceutical industry has made massive investment in 
pharmacological and chemical researches all over the world in an effort to discover much more potent drugs, rather, a few new drugs (Santhi and Sengottuvel. 2016). The Cassia fistula plant extracts were shown as potent antibacterial, antifungal, anti-inflammatory and antioxidant (Gupta, 2010) properties and the findings were done using different solvent extracts and parts of the plant. The chemical analysis of different parts of $C$. fistula has been reported. It was found to contain flavonoids, phenolic compounds and pro anthocyanidins (Luximon et al., 2002). C. fistula extracts have been reported for various pharmacological activities including antiinflammatory (Rajeswari et al., 2006), antioxidant (Irshad et al., 2012), antimicrobial (Irshad et al., 2013), wound healing properties (Kumar et al., 2006) and anticancer activity (Irshad et al., 2014).

The plant Cassia fistula is a tree $20-30 \mathrm{ft}$. high; trunk straight; bark smooth and palegrey when young, rough and dark-brown when old; braches spreading, slender. Leaves 9-16 in. long; main rachis pubescent; stipule minute. Leaflets 4-8 pairs, ovate or ovateoblong, acute, bright green and glabrous above, paler scent on the underside, base cuneate; main nerves numerous, close, conspicuous beneath; petiolules long, pubescent or glabrous. Flowers in lax racemes 12-20 in. long; pedicels long, slender, pubescent or glabrous. Calyx divided to the base, pubescent; segments oblong, obtuse. Corolla yellow; petals 5, sub-equal, obovate, shortly clawed, veined, stamens all antheriferous, Pods 1-2 ft. long, 1 in. in diam., pendulous, cylindrical, nearly straight, smooth, shinning, brown-black, indehiscent, with numerous (40-100) horizontal seeds immersed in a dark-colored sweetish pulp, and completely separated by transverse dissepiments. Seeds broadly ovate, slightly less in breadth, the plant flowers during March to May (Fig. 1).

\section{Materials and Methods}

\section{Selection of plant species}

The plant material (bark) of Cassia fistula was collected from the Osmania University campus, Hyderabad, Telangana, India. The plant's bark washed thoroughly 2-3 times with running tap water and once sterile with distilled water. Then the plant parts were shade dried and coarsely powdered separately and stored in well closed bottles for further analysis in laboratory.

\section{Extraction of the plant materials}

The fresh plant bark was washed with running tap water and shade dried and crushed to coarsely powder. This coarse powder $(25 \mathrm{~g})$ was then subjected to successive extraction in $250 \mathrm{ml}$ of ethanol, methanol, acetone, chloroform and also in water by using Soxhlet apparatus. The collected extracts were stored and then used for further analysis. The DMSO (Dimethyl sulfoxide) is act as dissolved solvents for these extracts.

\section{Quantitative Phytochemical Analysis}

\section{Estimation of Alkaloids}

Alkaloid determination by using Harborne (1973) method: One gram of the sample was weighed into a $250 \mathrm{ml}$ beaker and $200 \mathrm{ml}$ of $10 \%$ acetic acid in ethanol was added and it's covered and allowed to stand for $4 \mathrm{~h}$. It was filtered and the extract was concentrated on a water bath to one quarter of the original volume. Concentrated $\mathrm{NH}_{4} \mathrm{OH}$ was added by drop wise to the extract until the precipitation was complete. The whole solution was allowed to settle and the precipitate was collected and washed with dilute $\mathrm{NH}_{4} \mathrm{OH}$ and then filtered. The residue is the alkaloid, which was dried and weighed. 


\section{Estimation of Flavonoids}

One grams of plant sample was repeatedly extracted with $100 \mathrm{ml}$ of $80 \%$ of various aqueous solvents at room temperature. The mixture was filtered through a Whatman No1 filter paper into a pre-weighed $250 \mathrm{ml}$ beaker. The filtrate was transferred into a water bath and allowed to evaporate to dryness and weighed (Krishnaiah et al., 2009).

\section{Estimation of total phenols}

The fat free sample was boiled with $50 \mathrm{ml}$ of ether for the extraction of the phenolic component for $15 \mathrm{~min}$. Five $\mathrm{ml}$ of the extract was pipette out into a $50 \mathrm{ml}$ flask, then $10 \mathrm{ml}$ of distilled water was added. Two $\mathrm{ml}$ of $\mathrm{NH}_{4} \mathrm{OH}$ solution and $5 \mathrm{ml}$ of concentrated amyl alcohol were also added. The samples were made up to mark and left to react for 30 min for colour development. The absorbance was read at $505 \mathrm{~nm}$.

\section{Estimation of Carbohydrate}

$100 \mathrm{mg}$ of sample was hydrolyzed in a boiling tube with $5 \mathrm{ml}$ of $2.5 \mathrm{~N} \mathrm{HCl}$ in a boiling water bath for a period of 3 hours. It was cooled at room temperature and solid sodium carbonate was added until effervescence ceases. The contents were centrifuged and the supernatant was made to $100 \mathrm{ml}$ by using distilled water. From this $0.2 \mathrm{ml}$ of sample was pipette out and made up the volume to one $\mathrm{ml}$ with distilled water. Then one $\mathrm{ml}$ of phenol reagent was added and followed by $5.0 \mathrm{ml}$ of sulphuric acid. The tubes were kept at 25-30 $\mathrm{C}$ for $20 \mathrm{~min}$. The absorbance was read at 490 nm (Krishnaveni et al., 1984).

\section{Total Tannins Content Determination}

The tannins were determined by slightly modified Folin and Ciocalteu method. Briefly, $0.5 \mathrm{ml}$ of sample extract is added with $3.75 \mathrm{ml}$ of distilled water and added $0.25 \mathrm{ml}$ of Folin Phenol reagent, $0.5 \mathrm{ml}$ of $35 \%$ sodium carbonate solution. The absorbance was measured at $725 \mathrm{~nm}$. Tannic acid dilutions $(0$ to $0.5 \mathrm{mg} / \mathrm{ml}$ ) were used as standard solutions. The results of tannins are expressed in terms of tannic acid in $\mathrm{mg} / \mathrm{ml}$ of extract.

\section{Determination of total saponins}

The samples were ground and $20 \mathrm{~g}$ of each were put into a conical flask and $100 \mathrm{~cm} 3$ of $20 \%$ aqueous ethanol were added. The samples were heated over a hot water bath for $4 \mathrm{~h}$ with continuous stirring at about $55^{\circ} \mathrm{C}$. The mixture was filtered and the residue reextracted with another $200 \mathrm{ml} \mathrm{20 \%}$ ethanol. The combined extracts were reduced to $40 \mathrm{ml}$ over water bath at about $90^{\circ} \mathrm{C}$. The concentrate was transferred into a $250 \mathrm{ml}$ separatory funnel and $20 \mathrm{ml}$ of diethyl ether was added and shaken vigorously. The aqueous layer was recovered while the ether layer was discarded. The purification process was repeated. $60 \mathrm{ml}$ of n-butanol was added. The combined n-butanol extracts were washed twice with $10 \mathrm{ml}$ of $5 \%$ aqueous sodium chloride. The remaining solution was heated in a water bath. After evaporation the samples were dried in the oven to a constant weight; the saponin content was calculated (Obdoni and Ochuko, 2001)

\section{Determination of total Terpenoids}

$5 \mathrm{ml}$ of aqueous extract of each plant sample is mixed with $2 \mathrm{ml}$ of $\mathrm{CHCl}_{3}$ in a test tube $3 \mathrm{ml}$ of concentrated $\mathrm{H}_{2} \mathrm{SO}_{4}$ is carefully added to the mixture to form a layer. An interface with a reddish brown coloration is formed if terpenoids constituent is present.

\section{Determination of total Glycosides}

$1 \mathrm{ml}$ of concentrated $\mathrm{H}_{2} \mathrm{SO}_{4}$ is prepared in test tube $5 \mathrm{ml}$ of aqueous extract from each plant 
sample is mixed with $2 \mathrm{ml}$ of glacial $\mathrm{CH}_{3} \mathrm{CO}_{2} \mathrm{H}$ containing 1 drop of $\mathrm{FeCl}_{3}$. The above mixture is carefully added to $1 \mathrm{ml}$ of concentrated $\mathrm{H}_{2} \mathrm{SO}_{4}$ so that the concentrated $\mathrm{H}_{2} \mathrm{SO}_{4}$ is underneath the mixture. If cardiac glycoside is present in the sample, a brown ring will appear indicate.

\section{Results and Discussion}

The present study was carried out on the bark extracts of Cassia fistula revealed the presence of active phytochemical constituents in various solvents and the results are mentioned in table 1 and also the same is represented through graph 1-8. The quantitative estimation of primary metabolites revealed that the various phytochemical constituents present in the plant extract is as the content of the Alkaloid is $4.9 \mathrm{~W} / \mathrm{w}$ in ethanol and water extracts. While flavanoids and total phenols have shown their maximum content in water extracts as $4.4 \mathrm{~W} / \mathrm{w}$ and 5.3 $\mathrm{W} / \mathrm{w}$ respectively.

Table.1 Quantitative phytochemical analysis of Cassia fistula bark extracted with different polar, non-polar and aqueous solvents

\begin{tabular}{|c|c|c|c|c|c|c|c|}
\hline S.No. & $\begin{array}{c}\text { Phytochemical } \\
\text { Content in } \\
\text { bark (W/w) }\end{array}$ & \multicolumn{7}{|c|}{ Name of the Solvent } \\
\hline & & Ethanol & Methanol & Acetone & Chloroform & $\begin{array}{c}\text { Petroleum } \\
\text { Ether }\end{array}$ & Water \\
\hline $\mathbf{1}$ & Alkaloids & 4.9 & 4.7 & 4.5 & 4.3 & 4.7 & 4.9 \\
\hline $\mathbf{2}$ & Flavonoids & 4.3 & 4.6 & 2.7 & 2.9 & 0.9 & 4.4 \\
\hline $\mathbf{3}$ & Total Phenols & 4.6 & 5.2 & 4.6 & 4.8 & 3.9 & 5.3 \\
\hline $\mathbf{4}$ & Carbohydrate & 3.5 & 3.5 & 3.1 & 3.3 & 3.3 & 3.0 \\
\hline $\mathbf{5}$ & Total Tannins & 4.1 & 4.7 & 4.8 & 4.5 & 4.5 & 4.7 \\
\hline $\mathbf{6}$ & Saponins & 4.6 & 4.6 & 4.2 & 3.3 & 3.6 & 3.6 \\
\hline $\mathbf{7}$ & Terpenoids & 5.1 & 4.8 & 4.7 & 4.1 & 2.8 & 2.7 \\
\hline $\mathbf{8}$ & $\begin{array}{c}\text { total } \\
\text { Glycosides }\end{array}$ & 4.3 & 4.6 & 3.8 & 0.5 & 0.8 & 2.5 \\
\hline
\end{tabular}

Fig.1 Cassia fistula-habitat

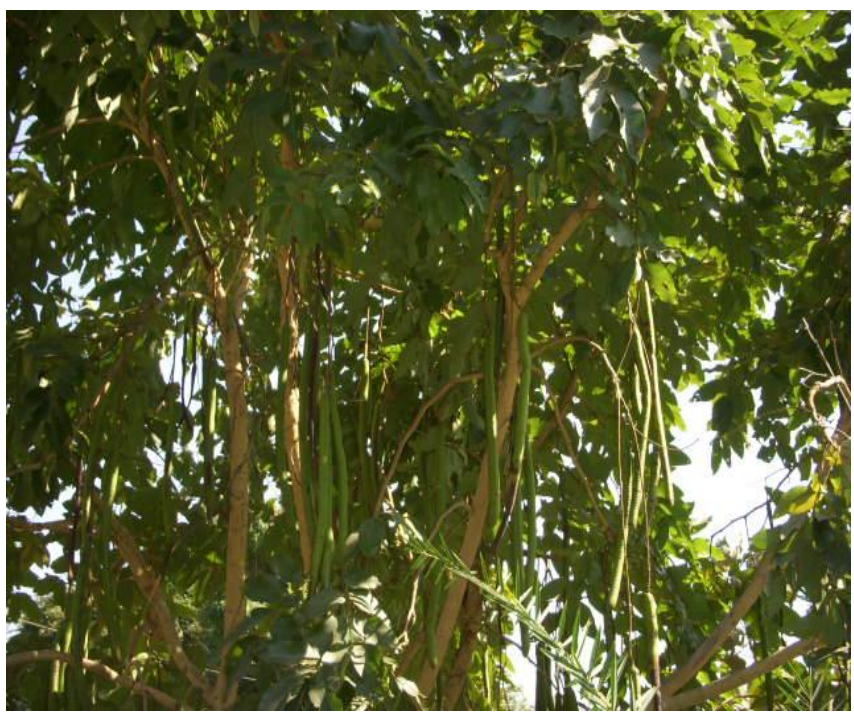



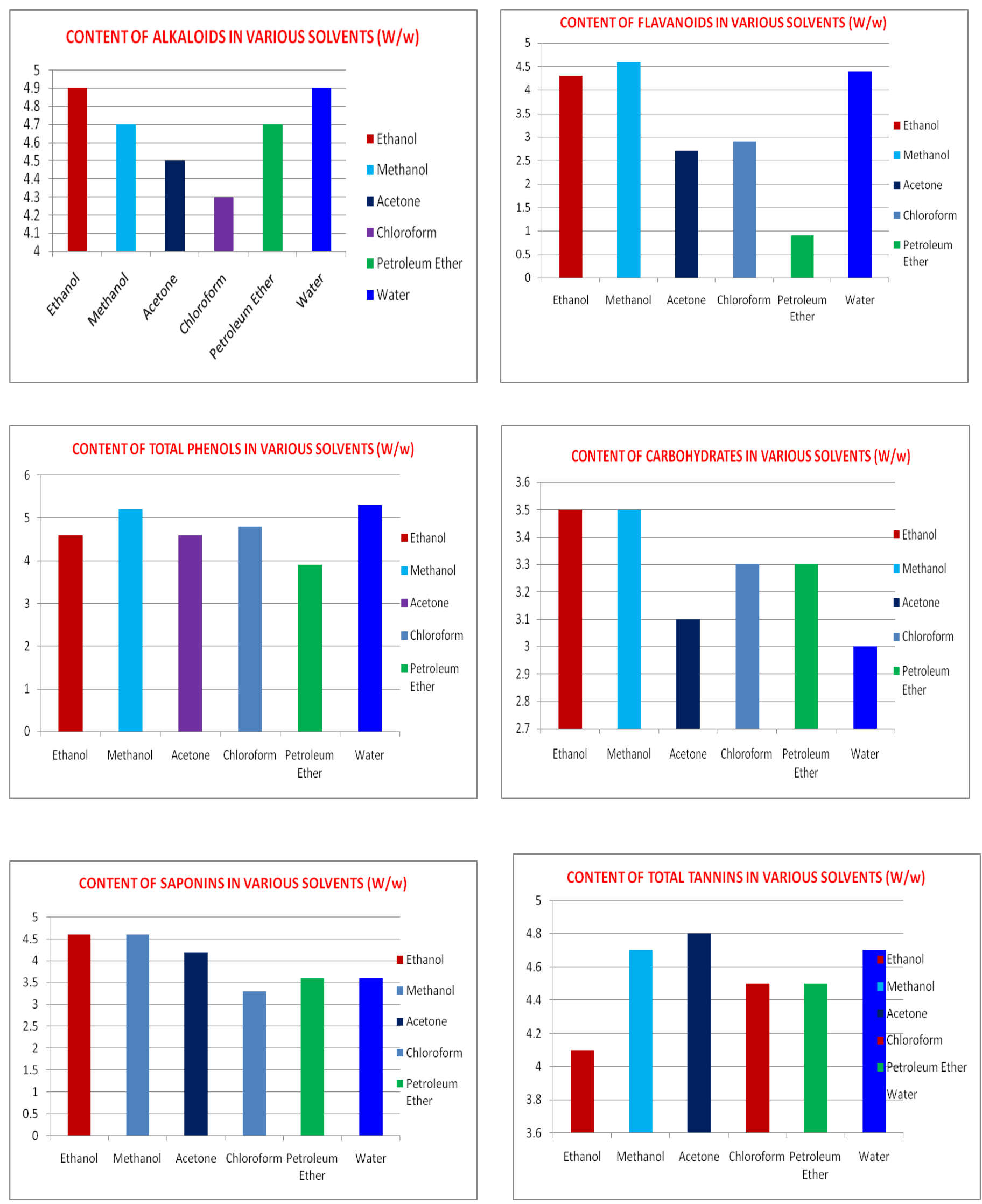


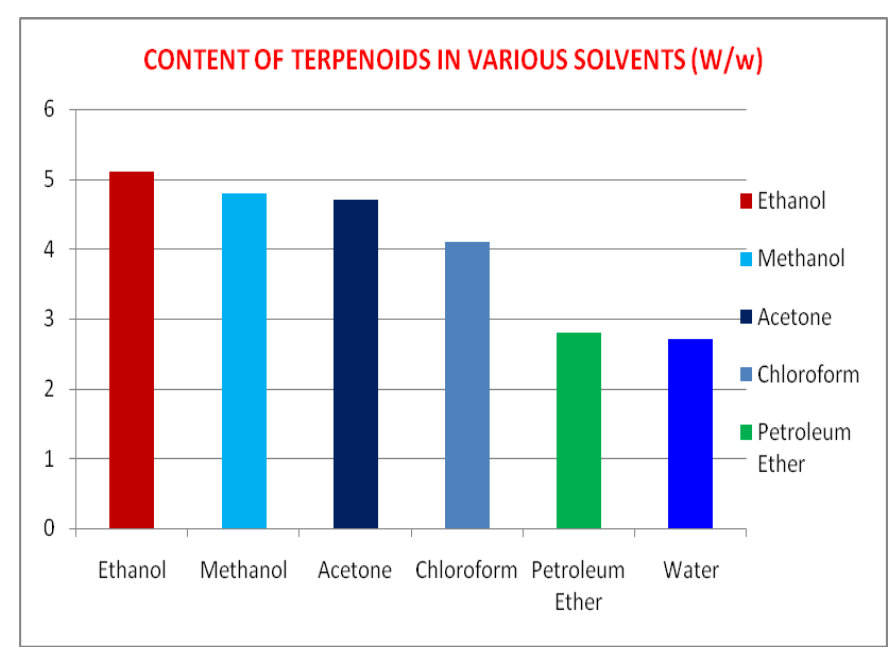

On the other hand, the content of carbohydrates are maximum in ethanol and methanol extracts as $3.5 \mathrm{~W} / \mathrm{w}$. a key observation is that total tannins are maximum in acetone extract as $4.8 \mathrm{~W} / \mathrm{w}$. Furthermore, saponins and total glycosides content is maximum in ethanol and methanol extracts as $4.6 \mathrm{~W} / \mathrm{w}$ and $4.6 \mathrm{~W} / \mathrm{w}$ respectively. Finally, terpenoids are extracted maximum in ethanol extract as $5.1 \mathrm{~W} / \mathrm{w}$.

In conclusion, Cassia fistula is an important source of naturally occurring bioactive compounds. The work so far achieved on Cassia fistula also sets the basis of future studies on the effects of its polyphenol containing extracts, which may have important practical implications for food quality and their potential utilization in multi component biological/food systems. It is becoming clear that traditional systems of medicine have become a topic of global importance. Cassia fistula could be one of them particularly because of its low toxicity and its widespread use for its multiple medicinal effects. The phytochemical compositions and biological activities need to be well understood and the data gathered so far for Cassia fistula and its extracts aim at achieving that goal.

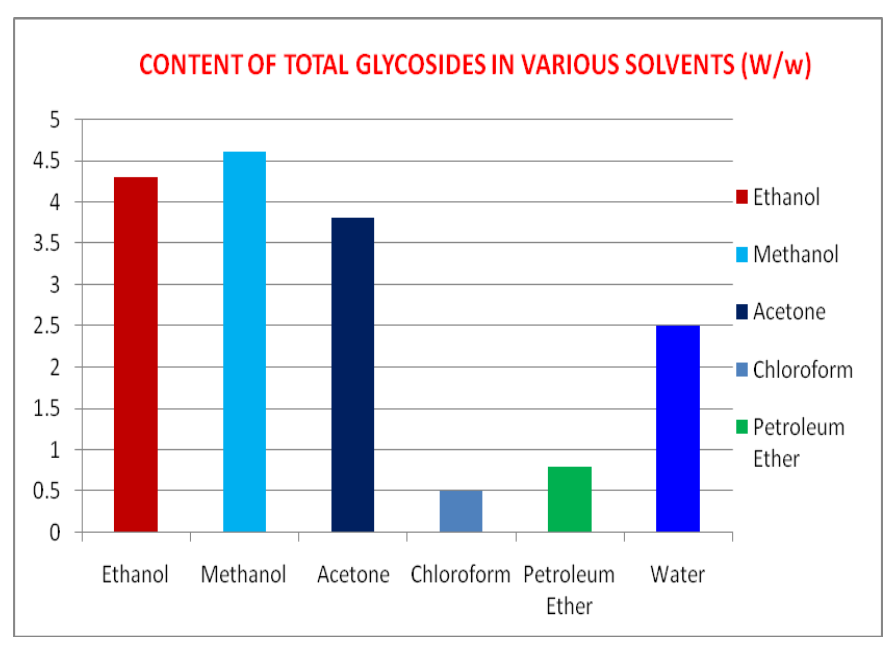

\section{Acknowledgement}

We are grateful to the authorities of Department of Botany, Osmania University, Hyderabad for providing the facilities for conducting this research and University Grants Commission-Post Doctoral Fellowship Scheme for providing the financial support in completion of this study.

\section{References}

Feroz, M., R. Ahmad., S.T.A.K. Sindhu and A.M. Shahbaz, (1993). Antifungal activities of saponin from indigenous plant roots. Pak. Vet. J., 13: 44.

Geisssman, T.A., (1963). Flavonoid compounds, Tannins, Lignins and related compounds, In $\mathrm{M}$.

Florkin and Stotz (Ed), Pyrrole Pigments, Isoprenoid compounds and phenolic plant constituents Vol. 9. 265.

Fransworth, N.R., and R.W. Morris, (1976). Higher plants, The sleeping Giant of Drug Development. Am. J. Pharm., 148: 46-52.

Santhi, K. and R. Sengottuvel. (2016). Qualitative and Quantitative Phytochemical analysis of Moringa concanensis Nimmo. Int.J.Curr.Microbiol.App.Sci.5(1): 633640 
http://dx.doi.org/10.20546/ijcmas.2016.501.0 64

Gupta RK, (2010). Medicinal and Aromatic plants, CBS publishers and distributors, 1st edition, 2010: 116-117.

Luximon RA, Bahroun T, Soobrattee MA, Aruoma OI, (2002). Antioxidant activities of phenolic, proanthocyanidins, and flavonoid components in extracts of Cassia fistula. J Agric Food Chem, 50: 50425047.

Rajeswari R, Thejomoorthy P, Mathuram LN, Narayana-Raju KVS, (2006). Antiinflammatory activity of Cassia fistula linn, bark extracts in sub-acute models of inflammation in rats. Tamilnadu J Vet Anim Sci, 5:193-199.

Irshad M, Singh M, Zafaryab M, Rizvi MMA, (2012). Comparative analysis of the antioxidant activity of Cassia fistula extracts. Int J Med Chem, 2012; doi:10.1155/2012/157125.

Irshad M, Aijaz A, Zafaryab M, Ahmad F, Manzoor N, Singh M, Rizvi MMA, (2013). Composition of Cassia fistula oil and its antifungal activity by disrupting ergosterol biosynthesis. Nat
Prod Commun, 8:261-264. Kumar VP, Chauhan NS, Padh H, Rajani M, (2006). Search for antibacterial antifungal agents from selected Indian medicinal plants. J Ethnopharmacol, 107:182-188.

Irshad M, Mehdi SJ, Al-Fatlawi AA, Zafaryab M, Ali A, Ahmad I, Singh M, Rizvi MMA, (2014). Phytochemical composition of Cassia fistula fruit extracts and its anticancer activity against human cancer cell lines. J Biol Active Prod Nat, 4 (3):158-170.

Krishnaiah, D., T. Devi, A. Bono and R. Sarbatly, (2009). Studies on phytochemical constituents of six Malaysian medicinal plants. J. Med. Plants. Res. 3(2): 67-72.

Krishnaveni, S., B. Theymoli., S. Sadasivam, (1984). Phenol Sulphuric acid method. Food chain., 15: 229.

Obdoni B, Ochuko P. (2001). Phytochemical studies and comparative efficacy of the crude extracts of some homostatic plants in Edo and Delta States of Nigeria. Global J. Pure Appl. Sci; 8: 203-208

\section{How to cite this article:}

Suman Kumar Ratnampally, Venkateshwar Chinna. 2017. Quantitative Analysis of Phytochemicals in the Bark Extracts of Medicinally Important Plant Cassia fistula, Linn. Int.J.Curr.Microbiol.App.Sci. 6(4): 1073-1079. doi: https://doi.org/10.20546/ijcmas.2017.604.133 